\title{
The Effect Of Ownership Structure On Future Stock Price Crash Risk: Korean Evidence
}

Soo Yeon Park, Chung-Ang University, South Korea

Younghyo Song, Korea University, South Korea

\begin{abstract}
This paper examines the effect of ownership structure on firm-specific stock price crash risk using listed firm (KOSPI) data in Korea. Prior literatures suggest that corporate governance has an impact on the level of disclosure and the quality. Managers may stockpile negative information about the company, but when such accumulated bad news crosses a threshold, the negative information suddenly becomes publicly available and a stock price crash is observed (Hutton, Marcus, \& Tehranian, 2009). Prior studies have documented the determinants of future stock price crash risk (Jin \& Myer, 2006; Hutton et al. 2009; Kim, Li, \& Zhang, 2011; Hamm, Li, \& Ng, 2013; Xu, Jiang, Chan, \& Yi, 2013; Jo, Moon, \& Choi, 2015; Kim \& Zhang, 2016). However, it is hard to find the papers about corporate ownership and future stock price crash risk at the term of determinants of the risk. Compare to some financially advanced countries where ownership and management are effectively separated, there is no clear distinction between ownership and management in Korea. Using the percentage of managerial ownership and that of foreign ownership as proxies for ownership structure and measures for future stock price crash risk which was used by Callen and Fang (2013, 2015) and Kim and Zhang (2016), we conducted an empirical analysis examining the link between corporate ownership structure and companies' subsequent stock price crash risk.
\end{abstract}

We collect 4,294 firm-year observations listed on Korean market from 2002 to 2015, and we use the measures of firmspecific stock price crash risk based on Callen and Fang $(2013$; 2015) to examine the relation between corporate ownership structure and subsequent stock price crash risk.

From the empirical tests, the percentage of managerial ownership is negatively associated with future stock price crash risk. It implies that managerial ownership increases to align the interests of shareholders and managers, it could alleviate the agency problem between them (Jensen \& Meckling, 1976), helping to resolve information asymmetry and prevent bad news from being withheld, ultimately lowering future stock price crash risk. In addition, we find that higher foreign ownership significantly weakens the negative relation between the percentage of managerial ownership and future stock price crash risk. We interpret this results that the negative side of foreign ownership failed to effectively reduce agency costs, weakening the negative correlation between managerial ownership and future stock price crash risk.

Our study may shed some light on the understanding of the ownership structure as a determinant of future stock price crash risk to firms and investors who want to handle crash risk in the stock market.

Keywords: Corporate Ownership Structure; Management Ownership; Foreign Investors; Stock Price Crash Risk

\section{INTRODUCTION}

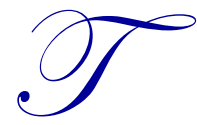

he purpose of this paper is to analyze the association between ownership structure and future stock price crash risk. In particular, we explored how ownership structure affects future stock price crash risk, by using the percentage of managerial ownership and that of foreign ownership as proxies for ownership structure. 
Managers may stockpile negative information about the company, but when such accumulated bad news crosses a threshold, the negative information suddenly becomes publicly available and stock price crash risk is increased (Hutton et al. 2009). Investors try to make reasonable investment decisions by accessing as much corporate information as they can, but a sudden and unexpected stock price crash could result in considerable loss to investors. Thus, investors and government agencies have increasingly become interested in exploring the determinants of stock price crash, and in fact, multiple studies have documented the determinants of stock price crash risk (Jin \& Myer, 2006; Hutton et al. 2009; Kim et al. 2011; Hamm et al. 2013; Xu et al. 2013; Kim \& Zhang, 2016; Jo et al. 2015).

Firm-specific stock price crashes occur when managers conceal bad news about the company from outside investors (Hutton et al. 2009). Managers engage in withholding bad news because agency conflicts exist between managers and investors (i.e., shareholders), leading to information asymmetry (Kothari, Shu, \& Wysocki, 2009). Where ownership and management are separated, managers have superior information and are motivated to pursue their own interest at the expense of shareholders' interest. Hence, if reporting adverse corporate information could cost managers their compensation, promotion opportunities or even jobs, they might attempt to relieve their career concerns by delaying the disclosure of bad news (Kothari et al. 2009). Thus, reducing agency conflicts could prevent managers from delaying the release of negative corporate information.

In mitigating agency conflicts, managers with equity interests play a key role. Unlike some financially advanced countries where ownership and management are effectively separated, there is no clear distinction between ownership and management in South Korea. In other words, one person can act both as manager and shareholder (Yoon \& Lee, 2005). As such, managers could incur agency costs, but at the same time, they are also motivated to control the costs. Generally, the higher managerial ownership is, the less conflict of interest there is between managers and shareholders, resulting in reduced agency costs (Jensen \& Meckling, 1976; Zajac \& Westphal, 1994; Warfield, Wild, \& Wild, 1995). Thus, managers with high equity interest are clearly motivated to disclose more information in order to maximize firm value (Nagar, Nanda, \& Wysocki, 2003). Under this logic, managerial ownership and the level of disclosure would be positively related; and as owner-managers would be less likely to delay the disclosure of bad news, managerial ownership and future stock price crash risk would be negatively related. On the other hand, managers with higher equity interest may incur agency costs since they are more likely to make decisions in their own best interests (Fama \& Jensen, 1983; Morck, Shleifer, \& Vishny, 1988; Park, 2003; Lee, Chun, \& Kim, 2012), causing the level of disclosure to deteriorate. Even if no agency conflicts arise, the level of disclosure would still diminish as ownermanagers are not under big pressure to disclose corporate information. This means there would be a significant negative correlation between the level of disclosure and managerial ownership (Mak, 1991; Eng \& Mak, 2003); and managers would be more likely to delay the release of bad news, so managerial ownership and future stock price crash risk would be positively related. Thus, it needs to be empirically confirmed whether a higher managerial ownership plays a positive or negative role in reducing agency costs, and how the percentage of managerial ownership affects information asymmetry and future stock price crash risk.

Meanwhile, it is reported that foreign investors are generally proactive in monitoring and supervising the management, requiring managers to make reasonable management decisions. Naturally, the existence of foreign investors would reduce agency costs as well as information costs arising from information asymmetry (Roh, Bae, \& Cheon, 2003; Kim \& Kim, 2007; Chung, Ho, \& Kim, 2004; Sachs \& Warner, 1995). In contrast, there is continuous criticism about how some foreign investors ask for higher dividends by taking advantage of their right as a large shareholder and focus on short-term profit harvesting and predatory investment strategy. As far as foreign ownership is concerned, there are conflicting views whether higher foreign ownership leads to positive or negative consequences. In this sense, we believe it would be worthwhile explaining how foreign ownership, a double-edged sword for business, affects agency costs and future stock price crash risk. And in case an owner-manager and a foreign investor both exist in one company, it is possible that agency costs could further be affected from the combined effects of managerial and foreign ownership. We took this into consideration and empirically examined the interaction effect between the percentage of managerial ownership and that of foreign ownership.

In our empirical analysis, we employed a measure for future stock price crash risk, which was used by Callen and Fang $(2013,2015)$. We examined the relation between ownership structure and future stock price crash risk over our sample firms, i.e., public companies listed on KOSPI from 2002 to 2015, and discovered the following results. First, there was significant negative association between the percentage of managerial ownership (measured by the 
percentage of common shares held by majority shareholder and related parties) and future stock price crash risk. This implies that higher managerial ownership aligns the interest between shareholders and managers, reducing the agency costs and information asymmetry (Jensen \& Meckling, 1976); as managers are less motivated to stockpile bad news, the possibility of future stock price crash is reduced. Second, the higher the proportion of foreign investors, the weaker the negative association between the percentage of managerial ownership and future stock price crash risk. While the presence of foreign investors and owner-managers each help lower future stock price crash risk, future stock price crash risk is not further mitigated if they both exist in one company - it is because the negative side of the foreign ownership failed to reduce agency costs effectively or because the proportion of managerial ownership is inversely proportional to that of foreign ownership.

This paper contributes to the current literature in several ways. First, by empirically proving that higher percentage of managerial ownership leads to lower stock price crash risk, we expand the discussion on the determinants of stock price crash risk. Specifically, we differentiate ours by showing the effect of managerial ownership, one of the internal corporate factors on stock price crash risk, that is not examined before. Second, we found that higher proportion of foreign investors weakens the negative association between managerial ownership and future stock price crash risk this proves the interaction effect between managerial ownership and foreign ownership, two important factors of corporate governance, on stock price crash risk. Third, while prior Korean evidence studies on stock price crash proxy for stock price crash risk using extreme price decreases, in line with Hutton et al. (2009), our analysis employed a measure for future stock price crash risk, which was used by Kim and Zhang (2016), Callen and Fang (2013; 2015). Thus, this paper complements the previous Korean evidence research on stock price crash risk.

The remainder of the paper is organized as follows. Section II reviews the previous literature and develops hypotheses used in the paper. Section III discusses the sample, variable measurements, and the research design, and Section IV presents the empirical test results and its interpretation. Finally, Section V concludes the paper.

\section{LITERATURE REVIEW AND HYPOTHESES DEVELOPMENT}

\subsection{Corporate Ownership Structure and Disclosures}

The purpose of corporate disclosure is to decrease the adverse selection arising from an information asymmetry between investors and managers, to share internal information with outside investors, and to lower firms' cost of capital (Diamond \& Verrechia, 2001). However, if ownership and management are separated, managers may be tempted to make a decision that could maximize their personal benefit, instead of corporate values. And when managers make such decision, they sometimes hoard or intentionally distort information. In other words, managers are motivated to voluntarily disclose reliable information, but at the same time they are tempted to hide or intentionally distort information to maximize their personal benefits. In this regard, various studies have been conducted on which determinants help prevent information asymmetry caused by agency cost, and how ownership structure impacts the level of disclosure.

Mak (1991) showed the negative relation between percentage of managerial ownership and the level of disclosure, while Hope and Thomas (2008) suggested that if the manager dominates the governance with his/her solid position, the company shows a lower level of disclosure. A study by Lee and Sohn (2005), measuring the level of disclosure proxied by the number of disclosures, indicated that the percentage of foreign and institutional investors' equity ownership are proportionate to the level of disclosure, and the percentage of managerial ownership is inversely proportionate to the level of disclosure. El-Gazzar (1998) demonstrated a positive relation between institutional investors' ownership and the level of voluntary disclosure, while Schadewitz and Blevins (1998) reported a negative relation between institutional investors' ownership and the level of disclosure.

\subsection{Stock Price Crash Risk}

There have been a number of studies on stock price crash determinants, and some have found them inside companies. Kim et al. (2011) proved that tax avoidance, opportunistic behavior of hiding negative information, is positively correlated to stock price crash. Kim and Zhang (2016) explored the association between conditional conservatism and stock price crash at the firm level. Their empirical analysis concluded that the level of conservatism had a significant 
negative relation with possibility of future stock price crash, and this relation was more evident in environments with higher information asymmetry, measured with R\&D costs, industry competitiveness and number of financial analysts. Jo et al. (2015) employed a market-based measure for future stock price crash risk of Hutton et al. (2009) and proved that higher comparability of accounting information lowers possibility of bad news being withheld inside the company, thereby reducing the risk of stock price crash.

Many researchers have studied external factors, in addition to factors internal to companies, as stock price crash determinants. Jin and Myer (2006) analyzed the association between stock price crash risk and opacity of the stock market by measuring transparency index, accounting standards, the number of accounting auditors in 40 countries. The research showed a positive relation between a company's opacity and stock price crash risk. Xu et al. (2013) proved a positive relation between the number of financial analysts and stock price crash risk based on data of China, an emerging market. As financial analysts in emerging markets disclose more overall market information than company-specific information, insufficient disclosure of company-specific information may lead to higher risk of stock price crash. Callen and Fang (2013) studied institutional investors' impact on stock price crash risk. Conflicting observations coexists, as some claim that institutional investors serve to monitor companies while others criticize them for their obsession with short-term profit and opportunistic behavior. Empirical analysis indicated that institutional investors mitigate stock price crash risk.

One important internal corporate factor impacting stock price crash is disclosure. Hutton et al. (2009) studied the correlation between opacity of financial statements and stock price crash risks. They measured corporate opacity proxy as discretionary accruals and produced an empirical analysis result showing that the opaquer financial statements are, the higher the risk of stock price crash. The result is meaningful that it discovered a nexus between mandatory disclosure and stock price crash risk by proving that the opacity of information provided through mandatory disclosures is positively related to stock price crash risk. Hamm et al. (2013) showed a positive relation between earnings guidance and stock price crash risk, which implies that earnings guidance plays more of an opportunistic role than an informational role. ${ }^{1}$ Earnings guidance is a voluntary disclosure, so this result also indicates a relation between voluntary disclosures and stock price crash risk. Song (2015) used data of 13 emerging market countries to show that companies with excellent disclosure policies are less likely to have stock price crash, suggesting that companies' disclosure policies have an impact on stock price crash risk.

Meanwhile, few studies have directly analyzed the impact of ownership structure on future stock price crash risk. Therefore, our study aims to focus on corporate ownership structure, such as managerial ownership and foreign ownership, and their impact on future stock price crash risk.

\subsection{Hypotheses Development}

Rational investors deem non-disclosure as bad news and depreciate corporate values, incentivizing managers to disclose their information (Grossman \& Hart, 1980; Milgrom, 1981; Verrechia, 1983; 2001). Also, non-disclosure of bad news might lead to litigation risk or reputation costs (Skinner, 1994), which prompts managers to disclose bad news too (Kasznik \& Lev, 1995; Skinner, 1994; 1997). However, reporting adverse corporate information could cost managers their compensation, bonus, their stock option price, promotion opportunities or even jobs, they might try to relieve their career concerns by delaying the disclosure of bad news (Kothari et al. 2009). Previous studies have reported that if such agency problems cause managers to withhold bad news within the company, which then exceeds threshold, stock price may crash (Hutton et al. 2009).

Convergence of interest hypothesis suggests that higher managerial ownership aligns interests of shareholders and managers, reducing agency costs and increasing corporate values (Jensen \& Meckling, 1976; Zajac \& Westphal, 1994; Warfield et al. 1995). Therefore, managers with higher ownership are more strongly motivated to maximize corporate values by disclosing more of their information to the market (Nagar et al. 2003). In this case, managerial ownership is positively related to the level of disclosure and negatively related to future stock price crash risk, as managers are less likely to delay reporting bad news.

${ }^{1}$ Earnings guidance help reduce information asymmetry between the managers and investors (Verrecchia, 2001), but may cause agency problem (Core, 2001; Healy \& Palepu, 2001).

Copyright by author(s); $\underline{\text { CC-BY }}$ 
In contrast, entrenchment hypothesis demonstrates that managers with high ownership increases agency costs by making decisions to benefit their own interests (Fama \& Jensen, 1983; Morck et al. 1988; Park, 2003; Lee et al. 2012), which may decrease the level of disclosure. And in cases where higher managerial ownership reduces agency costs, the level of disclosure may still decrease due to weaker pressure for disclosure. In these cases, therefore, managerial ownership and the level of disclosure have a significant negative relation (Mak, 1991; Eng \& Mak, 2003). As bad news is more likely to be withheld in this situation, managerial ownership can be assumed to be positively related to future stock price risk.

Therefore, the following null hypothesis is established for the relation between managerial ownership and future stock price crash risk.

Hypothesis 1: There is no significant relation between managerial ownership and companies' future stock price crash risk.

Foreign investors serve to reduce managers' agency costs through effective monitoring based on advanced techniques (Roh et al. 2003; Kim \& Kim, 2007; Chung et al. 2004; Sachs \& Warner, 1995). As foreign investors have more limited access to information compared to local investors, they are more active in monitoring managers in order to reduce costs of information asymmetry that might arise from such limited access (Sachs \& Warner, 1995).Therefore, if investors successfully play the role of reducing agency costs by using more advanced techniques to check managers, they can mitigate information asymmetry and prevent bad news from being withheld, thereby solidifying the negative relation, or weakening the positive relation, between managerial ownership and future stock price crash risk.

However, if foreign investors abuse their right as a large shareholder and ask for higher dividends and threaten managerial rights, or focus on short-term profit harvesting, they might undermine the company's long-term investment activities, impairing corporate values in the long run (Pound, 1988; Baysinger, Kosnik, \& Turk, 1991; Park \& Lee 2007; Kim \& Cheon 2004). In this case, if foreign investors fail to play their role of monitoring managers and adequately reducing agency cost and information asymmetry, foreign ownership can weaken the negative relation, or solidify the positive relation between managerial ownership and future stock price crash risk.

Therefore, the following null hypothesis is established for the impact of foreign ownership on the correlation between managerial ownership and future stock price crash risk.

Hypothesis 2: Foreign ownership has no significant impact on the relation between managerial ownership and companies' future stock price crash risk.

\section{SAMPLE AND METHODOLOGY}

\subsection{Sampling}

Our samples were selected from KOSPI listed companies from 2002 to $2015^{2}$. A total of 4,294 firm-years was used as samples. Financial data were extracted from Kis-Value Library, TS-2000 of Korea Listed Companies Association and Fn-Guide. Most Korean studies use for their financial and stock price data from these databases. Financial institutions, companies ending financial year in months other than December and companies whose financial statements and other important data are unavailable were excluded for consistency of samples. All variables are winsorized at top and bottom one-percentile to protect the results from the effects of extreme observations.

\subsection{Crash Risk Measures}

This study purposes to verify the relationship between corporate ownership structure and stock price crash, measured with managerial/foreign ownership. To verify this relation, we employed two primary measures of firm-specific stock price crash risk for each firm-year observation, following the previous literature (Chen et al. 2001; Hutton et al. 2009):

\footnotetext{
${ }^{2}$ This paper only used KOSPI-listed companies as samples, because of doubt on whether KOSPI-listed companies and KOSDAQ-listed companies are comparable, as they experience different economic events that can be used as proxies for their PER.
} 
(1) the negative coefficient of skewness of firm-specific daily returns (NCSKEW) and (2) the down-to-up volatility of firm-specific daily returns (DUVOL).

Specifically, we first estimate the following expanded market model regression for each firm and year (Hutton et al. 2009):

$$
\begin{aligned}
& \gamma_{i, t}=\beta_{0}+\beta_{1, t} \gamma_{m, t-2}+\beta_{2, t} \gamma_{m, t-1}+\beta_{3, t} \gamma_{m, t}+\beta_{4, t} \gamma_{m, t+1}+\beta_{5, t} \gamma_{m, t+2}+\beta_{6, t} \gamma_{k, t-2}+\beta_{7, t} \gamma_{k, t-1} \\
& +\beta_{8, t} \gamma_{k, t+1}+\beta_{9, t} \gamma_{k, t+2}+\in_{i, t}
\end{aligned}
$$

Where $\mathrm{r}_{\mathrm{i}, t}$ is the return on stock $\mathrm{i}$ in week $\mathrm{t}, \mathrm{r}_{\mathrm{m}, \mathrm{t}}$ is the return on the KOSPI value-weighted market index in week $\mathrm{t}$, and $\mathrm{r}_{\mathrm{i}, \mathrm{t}}$ is the return on the value-weighted industry index based on two-digit the Korean Standard Industrial Classification (KSIC) codes. Lead and lag variables for the market index are included to allow for non-synchronous trading (Dimson, 1979). We defined the firm-specific weekly return for firm $i$ in week $t\left(\mathrm{~W}_{\mathrm{i}, t}\right)$ as the natural logarithm of one plus the residual return in equation (1), that is, $\mathrm{W}_{\mathrm{i}, \mathrm{t}}=\ln \left[1+\varepsilon_{\mathrm{i}, \mathrm{t}}\right]^{3}$.

Our first measure of firm-specific stock price crash risk, NCSKEW, is computed as the negative of the third moment of firm-specific weekly returns each sample year and divided by the standard deviation of firm-specific weekly returns raised to the third power. Thus, for each firm i in year t, NCSKEW as

$$
\operatorname{NCSKEW}_{i, t}=-\left[n(n-1)^{\frac{3}{2}} \sum W_{i, t}^{3} /\left[(n-1)(n-2)\left(\sum W_{i, t}^{2}\right)^{3 / 2}\right]\right.
$$

where $\mathrm{W}_{\mathrm{i}, \mathrm{t}}$ is firm-specific weekly return as defined above, and $\mathrm{n}$ is observation numbers of firm specific returns during the fiscal year $t$. A negative sign is put in front of the third moment such that a larger value of NCSKEW signifies greater crash risk.

The second measure of firm-specific crash risk is called the down-to-up volatility measure (DUVOL).

$$
\operatorname{DUVOL}_{i, t}=\log \left\{\left(n_{u}-1\right) \sum_{d o w n}^{W_{i, t}^{2}} /\left(\mathrm{n}_{\mathrm{d}}-1\right) \sum_{u p}^{W_{i, t}^{2}}\right\}
$$

where $\mathrm{n}_{\mathrm{u}}$ and $\mathrm{n}_{\mathrm{d}}$ are the number of up and down weeks in year $\mathrm{t}$, respectively. A higher value of DUVOL corresponds to a higher stock price crash risk. More specifically, for each firm i over a fiscal-year period t, we separated all the weeks with firm-specific weekly returns into two groups: when the returns are below (above) the annual mean and call this "down" ("up") weeks. We further compute the standard deviation for the two predefined groups separately. We then calculate the natural logarithm of the ratio of the standard deviation of the "down" weeks to the standard deviation in the "up" weeks.

\subsection{Empirical Model and Variable Definitions}

We built the following model (4) to empirically analyze how firm's ownership structure influences subsequent stock price crash risk, using the percentage of managerial ownership and that of foreign ownership as proxies.

$$
\begin{aligned}
& \mathrm{CRASH}_{i, t+1}=\beta_{0}+\beta_{1} \mathrm{MNGR}_{i, t}+\beta_{2} \operatorname{SIZE}_{i, t}+\beta_{3} M B_{i, t}+\beta_{4} \text { ROA }_{i, t}+\beta_{5} \text { TRADING }_{i, t}+\beta_{6} \text { MNRET }_{i, t} \\
& +\beta_{7} \text { STDRET }_{i, t}+\beta_{8} \text { BETA }_{i, t}+\beta_{9} L E V_{i, t}+\beta_{10} O P A Q U E_{i, t} \\
& +\beta_{11} C_{R A S H} H_{i, t}+\text { YEAR DUMMY + INDUSTRY DUMMY }
\end{aligned}
$$

\footnotetext{
${ }^{3}$ The residuals from Eq. (1) is highly skewed, hence the logarithm transformation is performed to obtain a more symmetric distribution (Hutton et al. 2009).
} 
Where

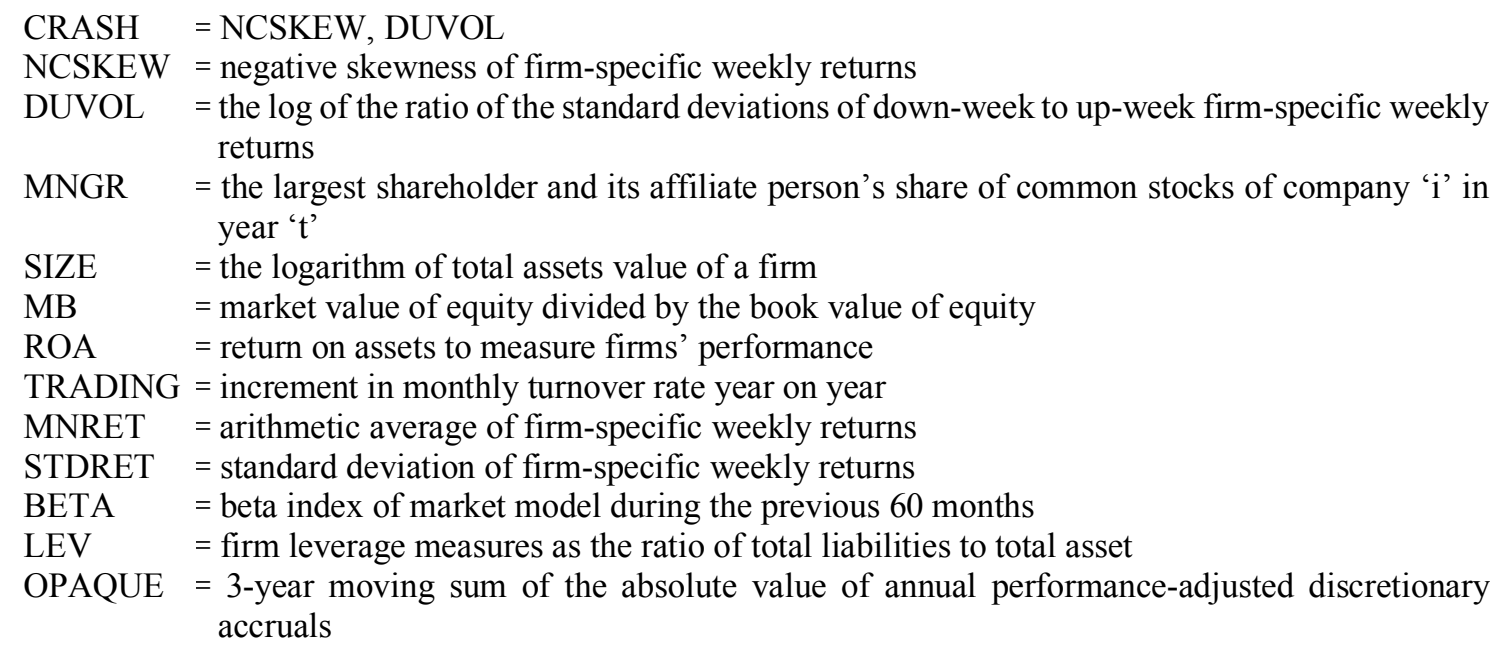

First, two measurements of crash risk, NCSKEW and DUVOL, are applied to the dependent variable CRASH. The independent variable of interest $\left(\beta_{1}\right)$ uses percentage of managerial ownership (MNGR) for verification of hypothesis 1. MNGR was measured as the proportion of managers' stake to the entire shares of a company. To be more specific, it was measured as the largest shareholder and its affiliated person's share of common stocks. The following control variables are controlled based on the previous studies (Chen et al. 2001; Hutton et al. 2009; Callen \& Fang, 2013 \& 2015; Jo et al. 2015) as they are known to have an effect on stock price crash risk: NCSKEW, DUVOL, SIZE, MB, ROA, TRADING, MNRET, STDRET, BETA, LEV, OPAQUE, Year Dummy and Industry Dummy.

Since the size of companies has a significantly negative relation with stock price crash risk, SIZE, or size of companies, was included in the regression equation to control size effect. And since MB and LEV have a positive relation with stock price crash risk (Kim, $\mathrm{Li}, \& \mathrm{Li}, 2014$ ), they were included in the equation to be controlled. TRADING is a proxy indicating the difference in investor opinions. Higher TRADING values, meaning bigger difference in opinions amongst investors, increases the risk of stock price crash (Chen et al. 2014), and was therefore controlled. OPAQUE can be used as a proxy indicating opacity of financial statements and was included in the equation to be controlled because the opaquer financial statements are, the more likely stock prices are to crash (Hutton et al. 2009).

Hypothesis 2 aims at verifying if foreign ownership weakens or strengthens the correlation between managerial ownership and future stock price crash risk. The following equation (5) is the model designed to verify it.

$$
\begin{aligned}
& \mathrm{CRASH}_{i, t+1}=\beta_{0}+\beta_{1} \mathrm{FRGN}_{i, t}+\beta_{2} \mathrm{MNGR}_{i, t}+\beta_{3} F R G N_{i, t} * M N G R_{i, t}+\beta_{4} \operatorname{SIZE}_{i, t}+\beta_{5} M B_{i, t} \\
& +\beta_{6} R O A_{i, t}+\beta_{7} \text { TRADING }_{i, t}+\beta_{8} \text { MNRET }_{i, t}+\beta_{9} \text { STDRET }_{i, t}+\beta_{10} \text { BETA }_{i, t} \\
& +\beta_{11} L E V_{i, t}+\beta_{12} \text { OPAQUE } E_{i, t}+\beta_{13} C_{R A S H} H_{i, t}+\text { YEAR DUMMY } \\
& + \text { INDUSTRY DUMMY }
\end{aligned}
$$

Where

FRGN $=$ the percentage of equity ownership by foreign investors

In this equation, FRGN, or foreign ownership, is measured with the foreign investors' share of common stocks. 


\section{RESULTS}

\subsection{Descriptive Statistics and Pearson Correlations}

Table 1 presents the sample distribution by year. Both crash risk measures (NCSKEW and DUVOL) have the highest crash risk in 2008 reflecting the financial crisis. Crash risk in 2012 is again considerably high, although not as high as during the financial crisis of 2008. This upward trend of stock price crash implies that many companies still fail to disclose negative information in a timely manner despite institutional and environmental changes such as the introduction of IFRS, tighter governance structure and external audits.

Table 1. Sample Distribution

\begin{tabular}{c|c|c|c|c}
\hline Year & Frequency & Percent & NCSKEW $_{\mathbf{t}+\mathbf{1}}$ & DUVOL $_{\mathbf{t + 1}}$ \\
\hline 2002 & 250 & 5.82 & -0.430 & -0.208 \\
\hline 2003 & 260 & 6.05 & -0.422 & -0.220 \\
\hline 2004 & 276 & 6.43 & -0.513 & -0.240 \\
\hline 2005 & 280 & 6.52 & -0.670 & -0.349 \\
\hline 2006 & 291 & 6.78 & -0.384 & -0.198 \\
\hline 2007 & 300 & 6.99 & -0.536 & -0.279 \\
\hline 2008 & 308 & 7.17 & -0.238 & -0.125 \\
\hline 2009 & 317 & 7.38 & -0.563 & -0.280 \\
\hline 2010 & 324 & 7.55 & -0.514 & -0.263 \\
\hline 2011 & 357 & 8.31 & -0.561 & -0.277 \\
\hline 2012 & 336 & 7.82 & -0.395 & -0.208 \\
\hline 2013 & 334 & 7.78 & -0.455 & -0.232 \\
\hline 2014 & 339 & 7.89 & -0.382 & -0.197 \\
\hline 2015 & 322 & 7.50 & -0.561 & -0.282 \\
\hline Total & 4,294 & 100.00 & -0.430 & -0.208 \\
\hline
\end{tabular}

Note: This table reports the sample distribution and mean values of stock price crash risk by year. The sample includes 4,294 firm-year observations in 2002-2015.

Table 2 shows descriptive statistics about the variables used in our regressions. In this study, values smaller (bigger) than $1 \%(99 \%)$ of the distribution of each variable were replaced with $1 \%(99 \%)$ values, in order to reduce the impact of outliers. The average values of subsequent crash risk measures, NCSKEW $\mathrm{t}_{\mathrm{t}+1}$ and $\mathrm{DUVOL}_{\mathrm{t}+1}$ are -0.471 and -0.238 , respectively. The mean DUVOL $\mathrm{t}_{t+1}$ is similar to the estimates in Chen et al. (2001), but that of $\mathrm{NCSKEW}_{\mathrm{t}+1}$ is slightly lower than those reported in Lee et al. (2016), possibly because of the different sample market. The average and median values of MNGR $\mathrm{t}$ are 0.426 and 0.424 respectively, showing that controlling shareholder ownership of listed companies in Korea is significantly high on average, reaching close to $43 \%$. The average FRGN $\mathrm{t}_{\mathrm{t}}$ is 0.091 , showing that foreign investors own an average of $9.1 \%$ of firms' entire equity ownership.

The average company size measured by the natural logarithm value of total asset, or SIZE $\mathrm{t}$, is 26.510 and the average of $\mathrm{MB}$ t, the ratio of book value to market value, an indicator of growth rate, is 1.033 . This means that the asset of sample companies showed market values similar to book values. The average $\mathrm{LEV}_{\mathrm{t}}$ and $\mathrm{ROA}_{\mathrm{t}}$ are 0.435 and 0.021 , respectively. The average of OPAQUE $t$, the sum of discretionary accruals over three previous years, is 0.258 . 
Table 2. Descriptive Statistics of the Main Variables

\begin{tabular}{l|r|r|r|r|r|r|r|r}
\hline \multicolumn{1}{c|}{ Variables } & Mean & Std. Dev. & $\mathbf{5 \%}$ & $\mathbf{2 5 \%}$ & \multicolumn{1}{|c|}{ MED. } & $\mathbf{7 5 \%}$ & $\mathbf{9 5 \%}$ \\
\hline NCSKEW $_{\mathbf{t}+\mathbf{1}}$ & -0.471 & 0.825 & -1.986 & -0.894 & -0.392 & 0.016 & 0.733 \\
\hline DUVOL $_{\mathbf{t}+\mathbf{1}}$ & -0.238 & 0.365 & -0.865 & -0.474 & -0.233 & 0.004 & 0.358 \\
\hline MNGR $_{\mathbf{t}}$ & 0.426 & 0.164 & 0.168 & 0.309 & 0.424 & 0.526 & 0.713 \\
\hline FRGN $_{\mathbf{t}}$ & 0.091 & 0.130 & 0.000 & 0.004 & 0.029 & 0.127 & 0.376 \\
\hline SIZE $_{\mathbf{t}}$ & 26.510 & 1.387 & 24.517 & 25.508 & 26.299 & 27.323 & 29.268 \\
\hline MB $_{\mathbf{t}}$ & 1.033 & 0.930 & 0.227 & 0.474 & 0.752 & 1.244 & 2.799 \\
\hline ROA $_{\mathbf{t}}$ & 0.021 & 0.088 & -0.118 & 0.006 & 0.032 & 0.062 & 0.120 \\
\hline TRADING $_{\mathbf{t}}$ & -0.021 & 0.445 & -0.608 & -0.071 & -0.006 & 0.037 & 0.462 \\
\hline MNRET $_{\mathbf{t}}$ & -0.002 & 0.007 & -0.014 & -0.006 & -0.002 & 0.002 & 0.011 \\
\hline STDRET $_{\mathbf{t}}$ & 0.056 & 0.025 & 0.027 & 0.040 & 0.051 & 0.066 & 0.107 \\
\hline BETA $_{\mathbf{t}}$ & 0.725 & 0.366 & 0.171 & 0.448 & 0.696 & 0.968 & 1.391 \\
\hline LEV $_{\mathbf{t}}$ & 0.435 & 0.203 & 0.106 & 0.280 & 0.438 & 0.581 & 0.773 \\
\hline OPAQUE $_{\mathbf{t}}$ & 0.258 & 0.587 & 0.023 & 0.065 & 0.111 & 0.180 & 0.949 \\
\hline
\end{tabular}

Note: This table reports descriptive statistics of the mean, median, and distributions of main variables used in this paper. All variables are winsorized at top and bottom one-percentile of the pooled data.

Table 3 shows the Pearson correlation coefficients among crash risk $\left(\right.$ NCKEW $_{t+1}$ and DUVOL ${ }_{t+1}$ ), percentage of managerial ownership (MNGR), the percentage of foreign ownership (FRGN), and other variables. In this table, NCKEW $_{t+1}$ and DUVOL $t+1$ are significantly and positively correlated with each other with a ratio of approximately 0.95 , which is comparable to that reported by Chen et al. (2001). MNGR thas a significant negative association with NCKEW $_{t+1}$ and DUVOL ${ }_{t+1}$, implying that the higher the proportion of managerial ownership, the more likely the firm has subsequent stock price crash risk. However, FRGN $t$ have a significant positive association with NCKEW $\mathrm{t}_{t+1}$ and DUVOL $_{t+1}$, implying that higher percentage of foreign ownership leads to relatively higher future stock price crash risk. However, since the crash risk variables are reported to have significant correlation with other controlled variables set in the research model, the result of simple analysis of association between two variables is not sufficient to adequately verify the hypothesis. Therefore, in the following paragraph, we will look at the result of a multivariate regression analysis, which verified the hypotheses after controlling other variables with possible impact on crash risks.

Table 4 provides the multivariate regression result of relation between managerial ownership and future stock price crash risk after controlling for other known determinants of crash risk. Column (1) and column (2) show that future stock price crash risk measurements, NCSKEW ${ }_{t+1}$ and DUVOL ${ }_{t+1}$, are significantly negatively associated with managerial ownership at $1 \%$ level. The finding indicates that higher managerial ownership means lower probabilities of future stock price crash risk. This result can be interpreted as suggesting that if managerial ownership increases to align the interests of shareholders and managers, it could alleviate the agency problem between them (Jensen \& Meckling 1976), helping to resolve information asymmetry and prevent bad news from being withheld, ultimately

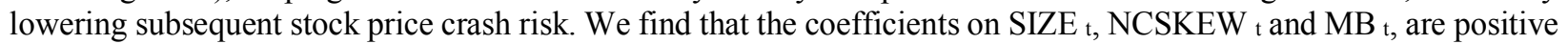
and significant across all three models, consistent with the findings of Chen et al. (2001). Also, we observe significantly negative coefficients on LEV $t$, which is similar to that reported by Hutton et al. (2009). 
Table 3. Pearson Correlation Between Variables Analyzed

\begin{tabular}{|c|c|c|c|c|c|c|c|}
\hline & NCSKEW $_{t+1}$ & DUVOL $_{t+1}$ & MNGR $_{t}$ & FRGN $_{t}$ & SIZE $_{t}$ & $\mathbf{M B}_{\mathrm{t}}$ & ROA $_{t}$ \\
\hline NCSKEW $_{\mathrm{t}+1}$ & $1.000^{* * *}$ & & & & & & \\
\hline DUVOL $_{t+1}$ & $0.950^{* * *}$ & 1.000 & & & & & \\
\hline MNGR $_{t}$ & $-0.066^{* * *}$ & $-0.053^{* * *}$ & 1.000 & & & & \\
\hline FRGN $_{t}$ & $0.145^{* * *}$ & $0.153^{* * *}$ & $-0.173^{* * *}$ & 1.000 & & & \\
\hline SIZE $_{t}$ & $0.203^{* * *}$ & $0.203^{* * *}$ & -0.005 & $0.467^{* * *}$ & 1.000 & & \\
\hline $\mathrm{MB}_{\mathrm{t}}$ & $0.125^{* * *}$ & $0.127^{* * *}$ & $-0.136^{* * *}$ & $0.218^{* * *}$ & $0.087^{* * *}$ & 1.000 & \\
\hline $\mathrm{ROA}_{\mathrm{t}}$ & $0.040^{* * *}$ & $0.036^{* *}$ & $0.144^{* * *}$ & $0.238^{* * *}$ & $0.183^{* * *}$ & -0.016 & 1.000 \\
\hline TRADING $_{\mathrm{t}}$ & $0.040^{* * *}$ & 0.024 & -0.011 & 0.005 & $0.028^{*}$ & 0.028 & $-0.029^{*}$ \\
\hline MNRET $_{\mathrm{t}}$ & $0.071^{\text {*** }}$ & $0.063^{* * *}$ & $0.062^{* * *}$ & $0.072^{* * *}$ & $0.078^{* * *}$ & $0.168^{* * *}$ & $0.301^{* * *}$ \\
\hline STDRET $_{\mathrm{t}}$ & $-0.065^{* * *}$ & $-0.083^{* * *}$ & $-0.140^{* * *}$ & $-0.230^{* * *}$ & $-0.274^{* * *}$ & $0.196^{* * *}$ & $-0.326^{* * *}$ \\
\hline BETA $_{t}$ & $0.050^{* * *}$ & $0.040^{* * *}$ & $-0.165^{* * *}$ & $0.093^{* * *}$ & $0.336^{* * *}$ & $0.151^{* * *}$ & -0.012 \\
\hline $\mathrm{LEV}_{\mathrm{t}}$ & $-0.035^{* *}$ & $-0.046^{* * *}$ & $-0.124^{* * *}$ & $-0.157^{* * *}$ & $0.122^{* * *}$ & $0.124^{* * *}$ & $-0.341^{* * *}$ \\
\hline OPAQUE $_{t}$ & 0.007 & 0.002 & -0.019 & $0.067^{* * *}$ & $0.127^{* * *}$ & -0.005 & 0.014 \\
\hline
\end{tabular}

\begin{tabular}{|c|c|c|c|c|c|c|}
\hline & TRADING $_{t}$ & MNRET $_{t}$ & STDRET $_{t}$ & BETA $_{t}$ & $\mathbf{L E V}_{t}$ & OPAQUE $_{t}$ \\
\hline TRADING $_{\mathrm{t}}$ & 1.000 & & & & & \\
\hline MNRET $_{t}$ & $-0.029^{*}$ & 1.000 & & & & \\
\hline STDRET $_{t}$ & $0.596^{* * *}$ & $0.068^{* * *}$ & 1.000 & & & \\
\hline BETA $_{t}$ & $0.197^{* * *}$ & -0.001 & $0.225^{* * *}$ & 1.000 & & \\
\hline $\mathrm{LEV}_{\mathrm{t}}$ & $0.185^{* * *}$ & $-0.089^{* * *}$ & $0.282^{* * *}$ & $0.192^{* * *}$ & 1.000 & \\
\hline OPAQUE $_{t}$ & $-0.059^{* * *}$ & 0.020 & $-0.042^{* * *}$ & -0.023 & -0.020 & 1.000 \\
\hline
\end{tabular}

Note: This table presents Pearson correlation between the future stock price crash risk variables, the corporate ownership variables, i.e. percentage of managerial ownership and that of foreign ownership, and other control variables. $* * *, * *$ and $*$ denote the significance level (two-tailed) at $1 \%$, $5 \%$ and $10 \%$ or less, respectively.

Table 4. Results of Multivariate Regression Analysis on the effect of managerial ownership on stock price crash risk $C_{R A S H_{i, t+1}}=\beta_{0}+\beta_{1} M N G R_{i, t}+\beta_{2}$ SIZE $_{i, t}+\beta_{3} M B_{i, t}+\beta_{4} R_{\text {OOA }}+\beta_{5, t}$ TRADING $_{i, t}+\beta_{6}$ MNRET $_{i, t}+\beta_{7}$ STDRET $_{i, t}$ $+\beta_{8}$ BETA $_{i, t}+\beta_{9} L E V_{i, t}+\beta_{10}$ OPAQUE $E_{i, t}+\beta_{11} C R A S H_{i, t}+$ YEAR DUMMY + INDUSTRY DUMMY

\begin{tabular}{|c|c|c|}
\hline Dep Var= & (1) NCSKEW $_{t+1}$ & (2) DUVOL DUt $_{t+1}$ \\
\hline Intercept & $-3.174^{* * *}$ & $-1.366^{* * *}$ \\
\hline MNGR $_{t}$ & $-0.322^{* * *}$ & $-0.126^{* * *}$ \\
\hline SIZE $_{t}$ & $0.119^{* * *}$ & $0.051^{* * *}$ \\
\hline $\mathrm{MB}_{\mathrm{t}}$ & $0.091^{* * *}$ & $0.046^{* * *}$ \\
\hline $\mathrm{ROA}_{t}$ & $0.062^{* *}$ & $0.019^{* * *}$ \\
\hline TRADING $_{\mathrm{t}}$ & $-1.553^{* *}$ & -1.003 \\
\hline MNRET $_{t}$ & $6.904^{* * *}$ & $2.903^{* * *}$ \\
\hline STDRET $_{t}$ & $-0.364^{* *}$ & $-0.188^{* * *}$ \\
\hline BETA $_{t}$ & -0.060 & -0.028 \\
\hline $\mathrm{LEV}_{\mathrm{t}}$ & $-0.418^{* * *}$ & $-0.248^{* * *}$ \\
\hline OPAQUE $_{t}$ & $-0.044^{* *}$ & $-0.022^{* *}$ \\
\hline NCSKEW(DUVOL) ${ }_{t}$ & $0.322^{* * *}$ & $0.051^{* * *}$ \\
\hline Year & \multicolumn{2}{|c|}{ Fixed } \\
\hline Industry & \multicolumn{2}{|c|}{ Fixed } \\
\hline Adjusted $\mathrm{R}^{2}$ & 0.095 & 0.106 \\
\hline \# of Samples & \multicolumn{2}{|c|}{4,294} \\
\hline
\end{tabular}

Note: This table presents the coefficient estimators of regression for managerial ownership $\left(M N G R_{t}\right)$ on future stock price crash risk $\left(N C S K E W{ }_{t+1}\right.$ and DUVOL $\left.{ }_{t+1}\right) . * * * * *$ and $*$ denote the significance level (two-tailed) at $1 \%, 5 \%$ and $10 \%$ or less, respectively.

Table 5 shows how foreign ownership impacts the effect of managerial ownership in lowering stock price crash risk. FRGN $t_{t}^{*}$ MNGR $t$, an interactive term of foreign ownership and managerial ownership, variables of interest of hypothesis 2 , presents a significantly positive association with two future stock price crash risk variables. Foreign ownership and managerial ownership each contributes to lowering future stock price crash risk, but if their interaction is considered, the effect of reducing crash risk becomes weaker. This implied that the negative association between managerial ownership and subsequent stock price crash risk is weakened with the negative side of foreign ownership 
failed to effectively reduce agency costs. This also seems to be relevant with the fact that managerial ownership and foreign ownership have statistically been substitutes. That is, higher managerial ownership reduces agency costs and prevents bad news from being withheld, thereby cutting crash risk, but a rise in foreign ownership comes at the expense of managerial ownership, weakening its role in lowering crash risks.

Table 5. Results of Multivariate Regression Analysis on the effect of foreign investor ownership on the relation between managerial ownership and stock price crash risk

\begin{tabular}{|c|c|c|}
\hline \multicolumn{3}{|c|}{$\begin{array}{l}\text { CRASH }_{i, t+1}=\beta_{0}+\beta_{1} \text { FRGN }_{i, t}+\beta_{2} \text { MNGR }_{i, t}+\beta_{3} F_{R G N_{i, t}} * M N G R_{i, t}+\beta_{4} \text { SIZE }_{i, t}+\beta_{5} M B_{i, t}+\beta_{6} \text { ROA }_{i, t}+\beta_{7} \text { TRADING } \\
+\beta_{8} \text { MNRET }_{i, t}+\beta_{9} \text { STDRET }_{i, t}+\beta_{10} \text { BETA }_{i, t}+\beta_{11} \text { LEV V }_{i, t}+\beta_{12} \text { OPAQUE } \\
i, t\end{array}$} \\
\hline Dep Var= & (1) NCSKEW $_{t+1}$ & (2) DUVOL $_{t+1}$ \\
\hline Intercept & $-3.253^{* * *}$ & $-1.366^{* * *}$ \\
\hline FRGN $_{t}$ & $-0.006^{* *}$ & $-0.002^{*}$ \\
\hline MNGR $_{t}$ & $-0.442^{* * *}$ & $-0.170^{* * *}$ \\
\hline $\mathrm{FRGN}_{\mathrm{t}} * \mathrm{MNGR}_{\mathrm{t}}$ & $0.014^{* *}$ & $0.006^{* *}$ \\
\hline SIZE $_{t}$ & $0.125^{* * *}$ & $0.052^{* * *}$ \\
\hline $\mathrm{MB}_{\mathrm{t}}$ & $0.094^{* * *}$ & $0.046^{* * *}$ \\
\hline $\mathrm{ROA}_{\mathrm{t}}$ & $-0.401^{* *}$ & $-0.245^{* * *}$ \\
\hline TRADING $_{t}$ & $0.063^{* *}$ & 0.019 \\
\hline MNRET $_{t}$ & $6.855^{* * *}$ & $2.899^{* * *}$ \\
\hline STDRET $_{t}$ & $-1.636^{* *}$ & $-1.023^{* * *}$ \\
\hline BETA $_{t}$ & -0.063 & -0.029 \\
\hline $\mathrm{LEV}_{\mathrm{t}}$ & $-0.374^{* * *}$ & $-0.187^{* * *}$ \\
\hline OPAQUE $_{t}$ & $-0.039^{*}$ & $-0.021^{* *}$ \\
\hline NCSKEW(DUVOL) $)_{\mathrm{t}}$ & $0.053^{* * *}$ & $0.050^{* * *}$ \\
\hline Adjusted $\mathrm{R}^{2}$ & 0.096 & 0.107 \\
\hline Year & \multicolumn{2}{|c|}{ Fixed } \\
\hline Industry & \multicolumn{2}{|c|}{ Fixed } \\
\hline \# of Samples & \multicolumn{2}{|c|}{4,294} \\
\hline
\end{tabular}

Note: This table presents the results of the impact of foreign investor ownership $\left(F R G N_{t}\right)$ on the relation between managerial ownership $\left(M N G R_{t}\right)$ and future stock price crash risk (NCSKEW ${ }_{t+1}$ and $\left.D U V O L_{t+1}\right)$. This table presents the coefficient estimators of regression for managerial ownership on. ${ }^{* *},{ }^{* *}$ and $*$ denote the significance level (two-tailed) at $1 \%, 5 \%$ and $10 \%$ or less, respectively.

\section{CONCLUSIONS}

In previous chapters, we explored how the corporate ownership influence companies' subsequent stock price crash risk. Using the percentage of managerial ownership and that of foreign ownership as proxies for ownership structure and market-based measure for future stock price crash risk which was used by Callen and Fang $(2013,2015)$ and Kim and Zhang (2016), we conducted an empirical analysis examining the link between corporate ownership and companies' future stock price crash risk. Compare to some financially advanced countries where ownership and management are effectively separated, there is no clear distinction between ownership and management in Korea.

If higher managerial ownership reduces agency costs and increases the level of disclosures, we would expect the negative relation between the percentage of managerial ownership and the future stock price crash risk. On the other hand, if higher managerial ownership incurs agency costs and decreases the level of disclosures, the percentage of managerial ownership could be positively related with the future stock price crash risk. As for foreign ownership, if foreign investors monitor managers effectively, foreign ownership could solidify the negative relation or weaken the positive relation between managerial ownership and the future stock price crash risk. Whereas if foreign investors fail to play their monitoring role, foreign ownership could weaken the negative relation or solidify positive relation between managerial ownership and the future stock price crash risk.

To test our hypotheses, we used firm-year observations from 4,294 companies listed on KOSPI over the period from 2002 to 2015 . We show the negative relation between the percentage of managerial ownership and future stock price crash risk. Also, we find that higher foreign ownership significantly weakens the negative relation between the percentage of managerial ownership and future stock price crash risk. 
Our study expands the researches on the determinants of stock price crash risk by empirically showing the negative relationship between managerial ownership and the stock price crash risk and is specifically meaningful to investigate the interaction effect of managerial and foreign ownership on stock price crash risk.

\section{AUTHOR BIOGRAPHIES}

Soo Yeon Park (1st author) is an assistant professor of School of Business Administration at Chung-Ang University in Korea. Research interests include voluntary disclosures, and other financial \& managerial accounting issues. Email: sypark1229@gmail.com

Younghyo Song (corresponding author) is a researcher of Institute for Business Research \& Education at Korea University in Korea. Research interests include voluntary disclosures, equity valuation, and other financial accounting issues. E-mail: syh0511@korea.ac.kr

\section{REFERENCES}

Baysinger, B. D., Kosnik, R. D. \& Turk, T.A. (1991). Effect of Board and Ownership Structure on Corporate R\&D Strategy. Academy of Management Journal, 34, 205-214.

Callen, J. L., \& Fang, X. (2013). Institutional investor stability and crash risk: Monitoring versus short-termism? Journal of Banking and Finance, 37(8), 3047-3063.

Callen, J. L., \& Fang, X. (2015). Short interest and stock price crash risk. Journal of Banking and Finance, 60, $181-194$.

Chen, J., H. Hong, \& Stein, J. C. (2001). Forecasting crashes: Trading volume, past returns, and conditional skewness in stock prices. Journal of Financial Economics, 61(3), 345-381.

Chung, R., Ho, S., \& Kim, J. B. (2004). Ownership structure and the pricing discretionary accruals in Japan. Journal of International Accounting, Auditing \& Taxation, 13, 1-20.

Core, J. (2001). A review of the empirical disclosure literature: Discussion. Journal of Accounting and Economics, 31, 441-456.

Diamond, D. W., \& Verrecchia, R. E. (1991). Disclosure, liquidity, and the cost of capital. The Journal of Finance, 46(4), 13251359.

Dimson, E. (1979). Risk measurement when shares are subject to infrequent trading. Journal of Financial Economics, 7(2), 197226.

El-Gazzar, S. (1998). Predisclosure information and institutional ownership: A cross-sectional examination of market revaluations during earnings announcement periods. The Accounting Review, 73(1), 119-129.

Eng, L. \& Mak, Y. (2003). Corporate governance and voluntary disclosure. Journal of Accounting and Public Policy, 22, 325345 .

Fama, E., \& Jensen, M. (1983). Separation of ownership and control. Journal of Law and Economics, 26(2), 301-326.

Grossman, S. J., \& Hart, O. (1980). Disclosure laws and takeover bids. Journal of Finance, 35, 323-334.

Hamm, S. J. W., Li, E. X. \& Ng, J. (2013). Management earnings guidance and stock price crash risk. Working Paper.

Healy, P. M., \& Palepu, K. G. (2001). Information asymmetry, corporate disclosure, and the capital markets: A review of the empirical disclosure literature. Journal of Accounting and Economics, 31, 405-440.

Hope, O.-K., \& Thomas, W. (2008). Managerial empire building and firm disclosure. Journal of Accounting Research, 46(3), 591-626.

Hutton A. P., Marcus, A.J., \& Tehranian, H. (2009). Opaque financial reports, R², and crash risk. Journal of Financial Economics, 94(1), 67-86.

Jensen M. C., \& Meckling, W. H. (1976). Theory or the firm: Managerial behavior, agency costs, and ownership structure. Journal of Financial Economics, 3(4)305-360.

Jin, L., \& Myer, S. C. (2006). R² around the world: New theory and new tests. Journal of Financial Economics, 79(2), $257-292$.

Jo, E., Moon, H. \& Choi, Y. (2015). The effect of comparability on firm-level stock price crash risk. Korean Accounting Review, 40(4), 179-211.

Kasznik, R., \& Lev, B. (1995). To warn or not to warn: Management disclosures in the face of an earnings surprise. The Accounting Review, 70, 113-34.

Kim, D. S., \& Cheon, Y. S. (2004). Foreign investors vs. domestic investors, who are better informed investors? Asia-Pacific Journal of Financial Studies, 33(2), 1-44.

Kim, M. T., \& Kim, Y. H. (2007). the impacts of foreign ownership and outside directors on bond grading. Korean Accounting Review, 32(4), 29-58.

Kim, J. B., Li, Y., \& Zhang, L. (2011). Corporate tax avoidance and stock price crash risk: Firm-level analysis. Journal of Financial Economics, 100(3), 639-662.

Kim, J. B. \& Zhang, L. (2016). Accounting conservatism and stock price crash risk: Firm-level evidence. Contemporary Accounting Research, 33(1), 412-441. 
Kim, Y., Li, H., \& Li, S. (2014). Corporate social responsibility and stock price crash risk. Journal of Banking \& Finance, 43, 113.

Kothari, S. P., Shu, S., \& Wysocki, P. D. (2009). Do managers withhold bad news? Journal of Accounting Research, 47(1), 241276.

Lee, A., Chun, S. \& Kim, S. (2012). Controlling shareholders' ownership structure and real earnings management. Korean Accounting Review, 37(1), 157-189.

Lee, J. W., \& Sohn, S. (2005). An empirical analysis of the relationship between corporate governance and corporate disclosure practices in Korea. Korean Accounting Review, 30(3), 33-69.

Mak, Y. (1991). Corporate characteristics and the voluntary disclosure of forecasts information: A study of New Zealand prospectuses. British Accounting Review, 23, 305-327.

Morck, R., Shleifer, A. \& Vishny, R. W. (1988). Management ownership and market valuation: An empirical analysis. Journal of Financial Economics, 20, 293-315.

Milgrom, P. (1981). Good news and bad news: Representation theorems and applications. Bell Journal of Economics, 12, 380391.

Nagar, V., Nanda, D., \& Wysocki, P. (2003). Discretionary disclosure and stock-based incentives. Journal of Accounting and Economics, 34(1-3), 283-309.

Park, J. I. (2003). Corporate governance and earnings management: View from the largest shareholders' holding. Korean Accounting Review, 28(2), 135-172.

Pound, J. (1988). Proxy contests and the efficiency of shareholder oversight. Journal of Financial Economics, 20, $237-265$.

Rho, J. H., Bae, G. S., \& Cheon, Y. (2003). Do firms with large agency costs choose high quality audits? A comparison of the audit quality between foreign-direct-investment-firms and local firms. Korean Accounting Review, 28(4), 203-230.

Sachs, J. D., \& Warner, A. (1995). Economic reform and the process of global integration. Brooking Papers on Economic Activity: 1-118.

Song, L. (2015). Accounting disclosures, stock price synchronicity and stock price crash: An emerging market perspective. International Journal of Accounting \& Information Management, 23(4), 349-363.

Schadewitz, H., \& Blevins, R. (1998). Major determinants of interim disclosures in an emerging market. American Business Review, 16(1), 41-55.

Skinner, D. (1994). Why firms voluntarily disclose bad news? Journal of Accounting Research, 32, 38-61.

Skinner, D. (1997). Earnings disclosures and stockholder lawsuits. Journal of Accounting and Economics, 23, $249-283$.

Verrecchia, R. (1983). Discretionary Disclosure. Journal of Accounting \& Economics, 5, 179-194.

Verrecchia, R. (2001). Essays on Disclosure. Journal of Accounting \& Economics, 32, 97-180.

Warfield, T.D., Wild, J. J., \& Wild, K. L. (1995). Managerial ownership, accounting choices, and informativeness of earnings. Journal of Accounting and Economics, 20(1), 61-91.

Xu, N., Jiang, X., Chan, K. C., \& Yi, Z. (2013). Analyst coverage, optimism, and stock price crash risk: Evidence from China. Pacific-Basin Finance Journal, 25, 217-239.

Yoon, S. M, \& Lee, M. J. (2005). The effect of separation of ownership and control on valuation in the Stock Market. The Review of Social \& Economic Studies, 25, 221-259.

Zajac, E. J. \& Westphal, J. D. (1994). The costs and benefits of managerial incentives and monitoring in large U.S. corporation: When is more no better? Strategic Management Journal, 121-142. 


\section{NOTES}

